УДК 378.011.3 - 051:373.3

DOI https://doi.org/10.24919/2308-4863/34-1-31

\author{
Ірина БАРДУС, \\ orcid.org/0000-0002-8682-7791 \\ доктор педагогічних наук, \\ доиент кафедри комп'ютерних технологій в управлінні та навчанні й інформатики \\ Бердянського держсавного педагогічного університету \\ (Бердянськ, Запорізька область, Украӥна) irina.bardus@gmail.com
}

Наталія ЧЕРВЯКОВСЬКА, orcid.org/0000-0003-3463-6333

аспірантка кафедри професійної освіти, трудового навчання та технологій

Бердянського держсавного педагогічного університету

(Бердянськ, Запорізька область, Украӥна) nataviktorovna.ch@gmail.com

\title{
ПРОБЛЕМИ ІНФОРМАТИЧНОЇ ПІДГОТОВКИ МАЙБУТНІХ УЧИТЕЛІВ ПОЧАТКОВОЇ ШКОЛИ У ЗАКЛАДАХ ФАХОВОЇ ПЕРЕДВИЩОЇ ОСВІТИ
}

Статтю присвячено проблемі підвищення якості професійної підготовки майбутніх учителів початкової школи в закладах фахової передвищої освіти, зокрема існуючим недолікам традичійної інформатичної підготовки иих фахівиів. У статті на основі аналізу професійної діяльності вчителя початкових класів, пов'язаної з використанням та навчанням інформаційних технологій відповідно до викликів Нової української иколи, визначено вимоги до його професійної компетентності, а також сучасні проблеми, пов'язані з ї формуванням під час навчання інформатичних дисииплін у закладах фахової передвищої освіти. Визначено, що професійна діяльність вчителя початкової школи охоплюе діяльність з організації, реалізації та управління освітнім прочесом. Для ефективного виконання цієї діяльності він має володіти інформачійно-цифровою, предметною, проєктувальною, інклюзивною, здоров'язбережувальною компетентностями та здатністю до формування мотивації й організації пізнавальної діяльності учнів. Формування цих професійних компетентностей у майбутніх учителів початкових класів у закладах фахової передвищої освіти має відбуватися під час оволодіння ними інформатичними дисциплінами. Однак, як засвідчив аналіз навчальних програм інформатичних дисииплін, їх кількість та зміст не дозволяє в повній мірі сформувати у здобувачів професійні компетентності вчителя початкових класів, необхідні для використання та навчання інформаџійних технологій. Сучасний зміст навчання дисииплін «Інформатика», «Новітні інформаиійні технології та технічні засоби навчання», «Практичний курс інформатики», «Методика навчання інформатики» характеризується несистемною і фрагментарною професійною спрямованістю та інтегрованістю з іншими дисциплінами. Наявні порушення логіки в послідовності навчання інформатичних та інших дисчиплін навчального плану підготовки. Подальші дослідження будуть присвячені розробленню методики професійно орієнтованого навчання інформатичних дисциплін майбутніх учителів початкової школи в закладах фахової передвищої освіти.

Ключові слова: учитель початкової школи, інформатика, професійна діяльність, професійна компетентність, Нова українська школа, фахова передвища освіта. 
Бардус I., Червяковська Н. Проблеми інформатичної пімготовки майьутніх учитемів ...

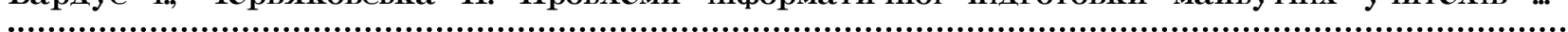

$$
\begin{array}{r}
\text { Irina BARDUS, } \\
\text { orcid.org/0000-0002-8682-7791 } \\
\text { Doctor of Pedagogical Sciences, } \\
\text { Associate Professor at the Department of Computer Technology } \\
\text { in Management and Education and Informatics } \\
\text { Berdyansk State Pedagogical University } \\
\text { (Berdyansk, Zaporizhia region, Ukraine) } \\
\text { irina.bardus@gmail.com }
\end{array}
$$

Natalia CHERVIAKOVSKA, orcid.org/0000-0003-3463-6333 Graduate Student at the Department of Vocational Education, Labor Training and Technology Berdyansk State Pedagogical University (Berdyansk, Zaporizhia region, Ukraine) nataviktorovna.ch@gmail.com

\section{PROBLEMS OF COMPUTER SCIENCE TRAINING OF FUTURE PRIMARY SCHOOL TEACHERS IN PROFESSIONAL COLLEGES}

The article is devoted to the problem of improving the quality of professional training of future primary school teachers in professional colleges, in particular the existing shortcomings of traditional computer science training of these specialists. The article, based on the analysis of professional activity of primary school teacher related to the use and teaching of information technology in accordance with the challenges of the New Ukrainian School, identifies the requirements for his professional competence, as well as current issues related to its formation during the study of computer science disciplines in professional colleges.. It is determined that the professional activity of a primary school teacher covers the organization, implementation, and management of the educational process. To effectively perform this activity, he must have information-digital, subject, design, inclusive, health-preserving competencies, and the ability to form motivation and organization of cognitive activity of students. The formation of these professional competencies in future primary school teachers in professional colleges should take place during their mastery of computer science disciplines. However, as evidenced by the analysis of curricula of computer science disciplines, their number and content does not allow to fully form the professional competencies of primary school teachers, necessary for the use and training of computer technologies. The modern content of teaching disciplines "Computer science", "Latest computer technologies and technical means of teaching", "Practical course of computer science", "Methods of teaching of computer science" is characterized by unsystematic and fragmentary professional orientation and integration with other disciplines. There are violations of logic in the sequence of learning computer science and other disciplines of the curriculum. Further research will be devoted to the development of methods for professionally oriented teaching of computer science disciplines to future primary school teachers in professional colleges.

Key words: primary school teacher, computer science, professional activity, professional competence, New Ukrainian school, professional pre-higher education.

Постановка проблеми. Інтеграція України в європейський освітній простір дала поштовх до кардинальних змін у системі загальної середньої та фахової передвищої освіти. У 2021 році набуде чинності оновлений професійний стандарт «Вчитель початкових класів закладу загальної середньої освіти», у зв'язку з чим сьогодні назріла нагальна потреба в перегляді системи професійної підготовки майбутніх учителів початкових класів відповідно до викликів Нової української школи в закладах фахової передвищої освіти (Проєкт професійного стандарту, 2020). Зважаючи на те, що новий вчитель початкових класів має бути здатним викладати на високому професійному рівні всі навчальні предмети, в тому числі й інформатику, під час розроблення освітніх програм підготовки цього фахівця в закладах фахової передвищої освіти окрему увагу необхідно приділити дослідженню існуючих проблем методики навчання інформатичних дисциплін.

Аналіз досліджень. Загальні питання підготовки вчителів в області теорії і методики навчання інформатики досліджені в роботах О. Пащенко, С. Бешенкова, О. Ракітіної, Л. Мілохіної, Н. Матвеєвої, Е. Міндзаєвої, О. Гейна, В. Житомирского, С. Лінецького, І. Роберт та інших. На їхню думку, інформатика $\epsilon$ найважливішим компонентом загальної освіти сучасної людини. В роботах Л. Босової, В. Буцик, А. Витухновської, С. Ільченко, Ю. Первіна, А. Семенова розкрито широкі потенційні можливості інформатики в розвитку дітей молодшого шкільного віку та обгрунтовано необхідність вивчення цієї дисципліни майбутніми вчителями початкової школи. 
Особливості підготовки фахівців для викладання пропедевтики інформатики та інформаційних технологій у початкових класах досліджували: Т. Гільберг, С. Тарнавська, Н. Павич, Ю. Первин, Л. Дзюба, А. Дрокіна, Н. Павлова, К. Музичук, О. Шиман та інші вчені. Незважаючи на велику кількість робіт науковців, присвячених підвищенню якості професійної підготовки майбутніх учителів початкової школи, досі залишаються малорозробленими проблеми навчання інформатичних дисциплін у закладах фахової передвищої освіти.

Мета статті - визначити сучасні проблеми інформатичної підготовки майбутніх учителів початкової школи в закладах фахової передвищої освіти.

Виклад основного матеріалу. Розроблення цілей та змісту навчання інформатичних дисциплін потребує визначення вимог до майбутнього вчителя початкової школи стосовно застосування та навчання ним інформаційних технологій. Для цього проаналізуємо професійну діяльність учителя початкової школи, яку він може виконувати після закінчення педагогічного коледжу.

Нами на основі структури виробничого процесу за В. Саловим (Салов, 2003) досліджено професійну діяльність учителя початкової школи 3 використання та навчання інформаційних технологій, структура якої наведена на рис. 1.
Як можна побачити 3 рис. 1, професійна діяльність учителя початкової школи охоплює діяльність $з$ організації, реалізації та управління освітнім процесом. Організація освітнього процесу включає в себе діяльність із добору і технічної підготовки обладнання навчального кабінету, забезпечення його функціонування та контроль функціонування під час освітнього процесу. Забезпечення роботи оснащення сучасного навчального кабінету початкової школи закладів загальної середньої освіти та підтримка його в робочому стані вимагає від учителя бездоганного володіння сучасним технічним приладдям і впровадження інформаційних технологій в усі види діяльності освітнього процесу. Майбутній педагог повинен викладати навчальні дисципліни 3 урахуванням найновіших досягнень науки та техніки, а також мати високий рівень сформованої інформаційноцифрової компетентності.

У проекті професійного стандарту (Проєкт професійного стандарту, 2020) під інформаційноцифровою компетентністю мається на увазі: здатність орієнтуватися в інформаційному просторі, здійснювати пошук і критично оцінювати інформацію, оперувати нею в професійній діяльності; здатність до використання відкритих ресурсів, інформаційно-комунікаційних та цифрових технологій в освітньому процесі; здатність до формування в учнів позитивного ставлення до інфор-

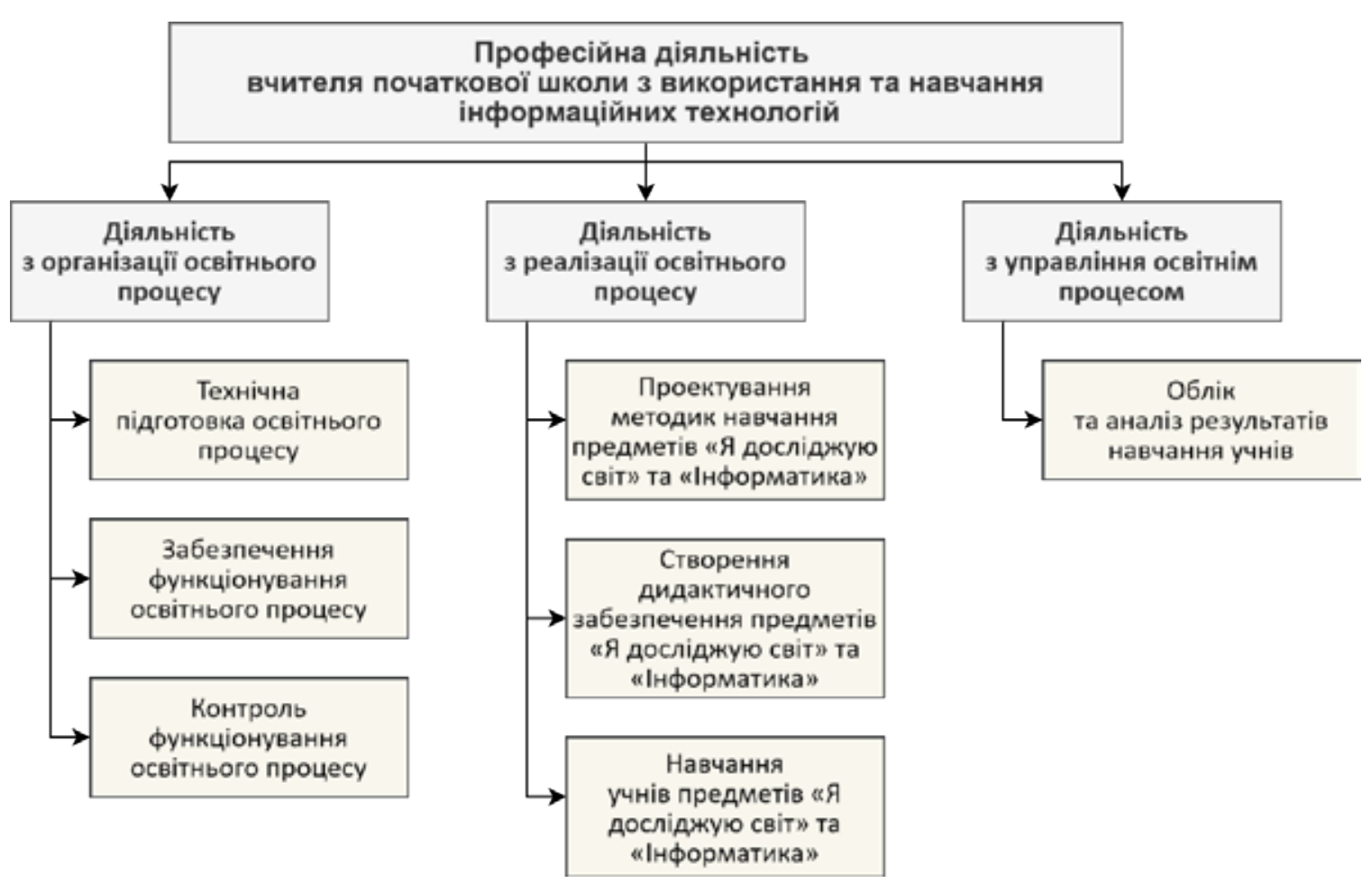

Рис. 1. Професійна діяльність учителя початкової школи з використання та навчання інформаційних технологій 
Бардус I., Червяковська Н. Проблеми інформатичної підготовки майьутніх учителів ...

маційно-комунікаційних та цифрових технологій та відповідального їх використання.

Для створення безпечного, а також ефективного інклюзивного освітнього середовища для дітей 3 особливими потребами вчитель також має володіти інклюзивною та здоров'язбережувальною компетентностями(Проєктпрофесійногостандарту,2020).

Інклюзивна компетентність передбачає володіння здатністю до забезпечення сприятливих умов в освітньому середовищі для кожного учня, залежно від його індивідуальних потреб, можливостей, здібностей та інтересів (Проєкт професійного стандарту, 2020).

Здоров'язбережувальна компетентність - це здатність до здійснення профілактичних заходів щодо збереження життя та здоров'я учнів (Проєкт професійного стандарту, 2020).

Наступним кроком розглянемо професійну діяльність учителя початкової школи 3 реалізації освітнього процесу. Навчальною програмою передбачено вивчення учнями у другому класі інтегрованого курсу «Я досліджую світ», до змісту якого включено модуль «Інформатика», а в третьому та четвертому класах Нової української школи (далі - НУШ) інформатика вже $є$ окремим предметом освітньої програми. Цей навчальний предмет спрямований на формування в учнів здатності до вирішення проблем 3 використання цифрових пристроїв, інформаційно-комунікаційних технологій та критичного мислення для розвитку, творчого самовираження, власного та суспільного добробуту; безпечної та відповідальної діяльності в інформаційному суспільстві (Гільберг, 2020).

Серед нововведень НУШ $є$ те, що інформатику в початкових класах має викладати саме вчитель початкової школи як людина, що формує світогляд своїх учнів (Первин, 2020). Учитель початкової школи у форматі НУШ - це такий собі «універсальний солдат». Педагог, вихователь, психолог, IT-фахівець в одній особі, основним обов'язком якого єздійснення цілісного педагогічного процесу відповідно до освітніх програм початкової школи.

Таким чином, для успішного виконання професійної діяльності з реалізації освітнього процесу, що включає в себе проектування методик навчання предметів «Я досліджую світ» та «Інформатика», розробку відповідного дидактичного забезпечення й безпосереднє викладання цих предметів, учитель початкової школи має володіти предметною, інформаційно-цифровою, проєктувальною, інклюзивною компетентностями, а також здатністю до формування мотивації та організації пізнавальної діяльності учнів (Проєкт професійного стандарту, 2020).

У проекті професійного стандарту під предмет- ною компетентністю мається на увазі: здатність до використання предметних знань в освітньому процесі; здатність до інтеграції предметних знань 3 різних освітніх галузей; здатність до добору й застосування доцільних форм, методів, технологій та засобів навчання.

Проєктувальна компетентність передбачає володіння здатністю до проєктування осередків навчання, виховання та розвитку учнів в освітньому середовищі.

I, нарешті, для виконання професійної діяльності з управління освітнім процесом, що передбачає діагностику та аналіз навчальних досягнень учнів, учитель має володіти також предметною, інформаційно-цифровою, інклюзивною компетентностями.

Отже, 3 проведеного аналізу професійної діяльності вчителя початкової школи, пов'язаної 3 використанням та навчанням інформаційних технологій, нами встановлено, що він має володіти інформаційно-цифровою, предметною, проєктувальною, інклюзивною, здоров'язбережувальною компетентностями, а також здатністю до формування мотивації та організації пізнавальної діяльності учнів.

Однак проведений нами аналіз науково-педагогічної та методичної літератури, освітніх програм і навчальних планів підготовки майбутніх молодших бакалаврів у закладах фахової передвищої освіти за професією «Вчитель початкових класів закладу загальної середньої освіти», а також робочих програм інформатичних дисциплін дозволив визначити певні суперечності між:

- зростаючими потребами суспільства в педагогах нової формації, здатних до впровадження сучасних IКТ, і недостатньою розробленістю теоретико-методичних засад їх підготовки в закладах фахової передвищої педагогічної освіти (Дрокіна, 2020);

- зростаючими вимогами до рівня сформованості предметної, інформаційно-цифрової, проєктувальної, інклюзивної компетентностей у майбутніх учителів початкової школи та недостатньою розробленістю теоретичних і методичних засад їх формування в процесі навчання інформатичних дисциплін.

Ми вважаємо, що поява цих суперечностей викликана низкою проблем, які назріли в системі професійної підготовки майбутніх учителів початкової школи у закладах фахової передвищої освіти.

Так, на нашу думку, для ефективної реалізації освітнього процесу з інформатики в школі, формування професійних компетентностей у майбутніх учителів початкових класів у закладах фахової 
передвищої освіти має відбуватися в повній мірі під час оволодіння ними інформатичними дисциплінами, оскільки їхні методи, форми та засоби $є$ дуже специфічними та відрізняються від методик навчання інших освітніх компонентів їхньої професійної підготовки.

Однак, як засвідчив аналіз навчальних програм інформатичних дисциплін, їх кількість та зміст не дозволяють у повній мірі сформувати у здобувачів професійні компетентності вчителя початкових класів, необхідні для використання та навчання інформаційних технологій. Наприклад, у змісті навчання інформатичних дисциплін майже не висвітлено технологію технічної підтримки технічних засобів навчання, технологію зйомки навчальних відеоуроків, застосування VR/AR технологій для навчання, використання технологій 3D-друку тощо.

Крім того, сучасний зміст навчання інформатичних дисциплін («Інформатика», «Новітні інформаційні технології та технічні засоби навчання», «Практичний курс інформатики», «Методика навчання інформатики») характеризується несистемною та фрагментарною професійною спрямованістю та інтегрованістю 3 іншими дисциплінами. Так, через відсутність професійної спрямованості дисципліна «Інформатика» студентами сприймається не як фундаментальна, а як одна із низки загальноосвітніх, через що знижу- ється рівень ії засвоєння та засвоєння інших дисциплін, які на неї спираються.

Наявні також порушення логіки в послідовності навчання інформатичних та інших дисциплін навчального плану підготовки майбутніх учителів початкової школи, які призводять того, що спочатку від студентів вимагають застосовувати на практиці ще не відомі їм технології, а потім уже їх вивчати.

Висновки. Отже, на основі аналізу професійної діяльності вчителя початкової школи 3 використання та навчання інформаційних технологій нами визначено, що він має володіти інформаційно-цифровою, предметною, проєктувальною, інклюзивною, здоров'язбережувальною компетентностями та здатністю до формування мотивації й організації пізнавальної діяльності учнів. Формувати ці компетентності доцільно під час навчання інформатичних дисциплін, що за традиційної системи підготовки $є$ малоефективним через наявність низки проблем, пов'язаних із низькою професійною спрямованістю та інтегрованістю цих дисциплін.

Подальші наші дослідження будуть присвячені розробленню методики професійно орієнтованого навчання інформатичних дисциплін майбутніх учителів початкової школи в закладах фахової передвищої освіти.

\section{СПИСОК ВИКОРИСТАНИХ ДЖЕРЕЛ}

1. Гільберг Т., Тарнавська С., Павич Н. Методика навчання інтегрованого курсу «Я досліджую світ» у 1-2 клаcax 33CO на засадах компетентнісного підходу : навчально-методичний посібник. URL: https://www.geneza.ua/sites/ default/files/product-images/Metodyky/Gilberg_Ya_doslid_svit_Metodyka_1.2kl.pdf (дата звернення: 18.11.2020).

2. Дрокіна А. С. Формування інформаційної компетентності майбутніх учителів початкової школи в процесі професійної підготовки : дис. ... канд. пед. наук : 13.00.04. Харків, 2020. 308 с.

3. Первин Ю.А. Раннее обучение информатике как государственная политика. URL: https:/cyberleninka.ru/ article/n/rannee-obuchenie-informatike-kak- gosudarstvennaya-politika (дата звернення: 10.11.2020).

4. Проєкт професійного стандарту за професіями «Вчитель початкових класів закладу загальної середньої освіти», «Вчитель закладу загальної середньої освіти». URL: https://mon.gov.ua/ua/news/mon-proponuye-dlya-gromadskogo-obgovorennyaproyekt-profstandartu-za-profesiyami-vchitel-pochatkovih-klasiv-zzso- vchitel-zzso/ (дата звернення: 10.11.2020).

5. Салов В. О. Основи педагогіки вищої школи. Дніпропетровськ : Національний гірничий університет, 2003. 183 с.

\section{REFERENCES}

1. Hilberh T., Tarnavska S., Pavych N. Metodyka navchannia intehrovanoho kursu «Ia doslidzhuiu svit» u 1-2 klasakh ZZSO na zasadakh kompetentnisnoho pidkhodu [Methods of teaching the integrated course «I explore the world» in 1-2 classes institutions of general secondary education on the basis of a competency approach]. Navchalno-metodychnyi posibnyk. URL: https://www.geneza.ua/sites/default/files/product-images/Metodyky/Gilberg_Ya_doslid_svit_Metodyka_ 1.2kl.pdf (data zvernennia 18.11.2020).

2. Drokina A. S. Formuvannia informatsiinoi kompetentnosti maibutnikh uchyteliv pochatkovoi shkoly v protsesi profesiinoi pidhotovky [Forming information competence of future primary school teachers in the process of professional training] : dys. ... kand. ped. nauk : 13.00.04. Kharkiv, 2020.308 p.

3. Pervyn Yu. A. Ranee obuchenye ynformatyke kak hosudarstvennaia polytyka [Early education in computer science as a public policy]. URL: https://cyberleninka.ru/article/n/rannee-obuchenie-informatike-kak-gosudarstvennaya-politika (data zvernennia: 10.11.2020). [in Russian].

4. Proiekt profesiinoho standartu za profesiiamy «Vchytel pochatkovykh klasiv zakladu zahalnoi serednoi osvity», «Vchytel zakladu zahalnoi serednoi osvity» [The project of the professional standard for the professions «Primary school teacher of general secondary education», «Teacher of general secondary education»]. URL: https://mon.gov.ua/ua/news/monproponuye-dlya-gromadskogo-obgovorennya-proyekt-profstandartu-za-profesiyami-vchitel-pochatkovih-klasiv-zzsovchitel-zzso/ (data zvernennia: 10.11.2020).

5. Salov V. O. Osnovy pedahohiky vyshchoi shkoly [Fundamentals of higher school pedagogy]. Dnipropetrovsk: Natsionalnyi hirnychyi universytet. 2003. $183 \mathrm{p}$. 